\title{
Cultural Difference of Customer Equity Drivers on Customer Loyalty: A Cross-National Comparison between South Korea and United States
}

\author{
DOI: 10.12776/QIP.V21I2.881
}

\author{
Insu Cho, Yong Soo Jang
}

Received: 12 February 2017 Accepted: 29 April $2017 \quad$ Published: 31 July 2017

\begin{abstract}
Purpose: Many advanced discount stores could not reach the certain growth level due to cultural differences and their marketing strategies that have failed to adopt in local market environment. The purpose of this study is to find the effects of customer equity drivers on customer loyalty and to examine cultural differences between South Korea and United States.

Methodology/Approach: This study sets independent variables of value equity, brand equity and relationship equity from the customer equity model and tests to see how each equity driver affects customers' loyalty through gaining their trust and satisfaction in the discount store industry. We applied structural equation model to test the hypothesis. We conducted a survey on customers who had shopping experiences in discount stores and gathered data from United States and South Korea respectively.

Findings: The results show that there are significant differences in the effects of customer drivers on customer loyalty via trust and satisfaction in large retail industries. While Satisfaction had some effects on building their loyalty in Korea, satisfaction had no effect in gaining customers' loyalty in USA.

Research Limitation/implication: The results of this study are highly relevant for managers who must make strategic marketing decisions for different cultures.

Originality/Value of paper: This study is the first systematic cross-cultural examinations on how customer equity drivers in discount stores affect customer loyalty between USA and South Korea.
\end{abstract}

Category: Research paper

Keywords: cross cultural research; customer equity; trust; loyalty; discount stores 


\section{INTRODUCTION}

Discount retail businesses in Korea have experienced dramatic changes with many multinational corporations entering the market. When retailers enter into other markets, they are advised not to adopt a standardized marketing approach. Because consumers in different countries may have different shopping experiences even in the same type of stores, retailers should consider cultural and environmental differences in local market. For example, Wal-Mart, the biggest discount retail stores in USA, entered South Korea in late 1990s for its international expansion, but failed to survive in this market and left Korea in 2005 as the American way of marketing did not work well in Korea. Of course there were other reasons of Walmart's failures but it is certain that cultural differences existed between Western (USA) and Eastern (Korea) cultures. The customer equity framework (Rust, Lemon and Zeithaml, 2004) suggests that three factors are of particular importance in building a customer base: value equity, brand equity and relationship equity. The model "customer equity drivers" has been researched widely and the similar context have been proposed and tested in many industries such as the European retailing (Vogel, Evanschitzky and Ramaseshan, 2008). But in this model, the influence of cultural differences on perceptions of customer benefits should be considered as critical factors for customer equity drivers. In response, Rust, Lemon and Zeithaml (2004) suggested that it is necessary to empirically validate in what kind of cultures various drivers are more important and less important. We try to find the answer for this suggestion by examining how each equity driver differ on customers' loyalty through gaining their trust and satisfaction in the discount store industry between Eastern (e.g, Korea) and Western (e.g, USA) cultures.

In order to maximize the long-term performance of multinational corporation (MNC), MNC managers should find core factors in specific driver(s) of customer equity and launch suitable programs to enhance it (Ramaseshan, Rabbanee and Tan Hsin Hui, 2013).

Our findings can provide a theoretical framework of the cultural relationships. Moreover, the results can be meaningful for MNC managers who must make strategic marketing decisions from domestic market to a new foreign market.

The remainder of this article is organized as follows: We first present an overview of the theoretical and empirical literature and develops the research hypotheses. We outline procedures to collect and analyse data from two countries, USA and Korea, using statistical methods. Based on the data analysis, we interpret the results to the hypotheses related to the effects of the customer equity drivers on customer loyalty via trust and satisfaction in the discount stores. We then discuss whether the research hypotheses were accepted or not, and offer implications for managers and future researchers. 


\section{THEORETICAL BACKGROUND}

\subsection{Cultural Frames that Explain Differences between the USA and Korea}

The key for explaining cultural difference in behavioural sciences is to focus on cultural values (Bond and Smith, 1996). Perhaps the best known cultural framework is Hofstede and Hofstede (2001) five-dimensional one: individualism versus collectivism, uncertainty avoidance, long-versus short-term orientation, power distance, and masculinity versus femininity. The first two dimensions are important for consumer behaviour and therefore should be relevant for understanding cross-national cultural difference in customer equity drivers for loyalty intentions.

In Hofstede and Hofstede (2001) cultural dimensions, the USA represents individualism, weak uncertainty avoidance, and short-term orientation, while Korea represents collectivism, strong uncertainty avoidance and long-term orientation. Collectivism is the tendency to place group goals above individual goals. In a collectivist culture, people tend to behave according to the social norms so people more likely to reply on others for their purchase decision and rely on reference groups for making judgments about decision making. whereas people in individualistic cultures value independence and self-sufficiency (Liu and McClure, 2001). Thus, people in an individualistic society are less likely to rely on others (e.g., family members, peers, social groups) in their purchase decisions.

Uncertainty avoidance is defined as "the degree to which people in a society tolerate ambiguity and uncertainty or feel threatened by ambiguous situations" (Atuahene-Gima and Li, 2002). This concept explains cultural differences in new change by which people prefer stability, predictability, and low stress rather than new experiences. So people with high uncertainty avoidance are less likely to purchase new products (Lowe and Corkindale, 1998) or less-established brands (Bao, Zhou and Su, 2003) and more likely to reply on price as an indicator of quality (Shapiro, 1973).

The USA and Korea are also opposites in Fukuyama's high-versus low-trust society. According to Fukuyama (1995), culture determines the level of trust that accumulates in the social capital capable of producing economic success. $\mathrm{He}$ defines trust as the degree to which people believe others act responsibly and for the common good. He identifies the USA, Japan, and Germany as high-trust societies, while Korea, China and France are low-trust societies.

The authors perceive that such cultural dimensions will have a profound impact on the way consumers perceive and behave, thus influencing the formation of trust and loyalty. Therefore, we propose to measure the effects of customer equity drivers on customer loyalty in large retail stores of two cultural groupsAmerican who are characterized as individualistic and low uncertainty avoidance 
and Korean who are characterized as collectivistic and high avoidance in this study.

\subsection{Conceptual Framework}

There are several studies that conducted research on relationship with customer equity drivers and loyalty intention (Dwivedi, et al., 2012; Vogel, Evanschitzky and Ramaseshan, 2008) as well as in cultural difference that studied (Zhang, Van Doorn and Leeflang, 2014). While, most of these studies essentially focused on B2C context, similar studying has been investigated in a B2B context to find the effects of customer equity drivers on customer loyalty via customer trust (Ramaseshan, Rabbanee and Tan Hsin Hui, 2013). Furthermore, the relationships among loyalty, satisfaction, and trust in retailing contexts have been studied widely and consistent results have been reported. That is, trust-satisfaction (Singh and Sirdeshmukh, 2000), trust-loyalty (Reichheld and Schefter, 2000), and satisfaction-loyalty (Park and Kim, 2003; Yang and Peterson, 2004) links are well established in both online and offline retailing settings in the USA and Korea. So we build the customer equity model of Rust, Lemon and Zeithaml (2004) with combination of trust-satisfaction-loyalty link in large retail store industries to test whether and how the importance of customer equity drivers varies between two countries.

Value equity refers to customer's evaluation of the product based on its utility. Brand equity is a subjective appraisal of customers regarding the brand and is more concerned with its image. Relationship equity involves special relationship bonds that link customers to the company. Trust can be defined as a feeling of security and willingness to depend on someone or something (Chung and Kwon, 2009). Satisfaction is regarded a key outcome of buyer-seller relationships (Anderson, Fornell and Lehmann, 1994). Store satisfaction represents a consumer's overall evaluation of the experience with a specific type of store, that is, a large retail stores like Walmart or Costco. Loyalty is signified by an intention to perform a diverse set of behaviours that signal a motivation to maintain a relationship with the focal firm, engaging in positive word-of-mouth, and repeat purchasing (Sirohi, McLaughlin and Wittink, 1998; Zeithaml, 1988). 


\section{HYPOTHESE DEVELOPMENT}



Figure 1-Research Model

\subsection{Value Equity and Trust}

Lemon, Rust, and Zeithaml (2001) defined value equity as "customer's objective assessment of the utility of a brand, based on perceptions of what is given up for what is received". It is the perceived ratio between what is received (such as the product and its different benefits) and what is sacrificed (such as the price paid for the product) and thus a higher benefits-cost ratio will yield higher value equity. Value is the keystone of the customer's relationship with the retailers. While judging value of retailers, consumers tend to group pricing, convenience, and quality of product information as aspects of a brand. When a firm delivers such aspects of value equity, it leads to enhanced customer trust and satisfaction and also higher repurchase-intentions (Eggert and Ulaga, 2002). De Mooij and Hofstede (2011) propose that, western consumers adopt a rational decision making style and thus are more price and quality oriented. Brady, Robertson and Cronin (2001) also state that Western consumers care more about the pricequality ratio and previous literature further state that low price and consistent quality affect U.S consumers' loyalty (Lee and Ulgado, 1997). However, Korean consumers possess a lower price consciousness and value for money orientation than U.S consumers. This is probably due to their concerns about face or relationship. These social needs may cause Korean consumers to pay less attention to intrinsic attributes, such as price and quality. Furthermore, Korean consumers in high collectivism cultures, they tend to be influenced by group members and pay attention to others' opinion (Hofstede and Hofstede, 2001). Overall, we expect that due to the influence of face concerns, cultures, and 
different decision making style, value equity should have less impact on trust in Korea than United States. So we propose the following hypothesis.

H1: The effect of value equity on trust is higher in United States than in Korea.

\subsection{Brand Equity and Trust}

Brand equity is a more subjective appraisal of the brand and is more related with abstract image and meaning than the rational factors such as price, quality and convenience (Lemon, Rust and Zeithaml, 2001; Rust, Lemon and Zeithaml, 2004). If customers perceive a particular brand as strong, unique and desirable, they experience high brand equity (Verhoef, Langerak and Donkers, 2007). A brand attaches additional intangible value to products or services compared to non-branded products or services (Vogel, Evanschitzky and Ramaseshan, 2008) and thus attracts customers' trust. Trust in familiar brands enables customers to feel secured and reliable (Delgado-Ballester and Luis Munuera-Alemán, 2001). Previous literature states that brands are especially important in Asia countries (ie Korea) (Henderson, et al., 2003), because brand loyalty enables Korean consumers to keep, save and gain face. Unlike in Western cultures, brand consumption does not merely fulfill material needs but also meets social needs, the preference to be respect by others (Ting-Toomey and Kurogi, 1998). Consumers in a culture of collectivism and high uncertainty avoidance are more likely to form trust via a transference process than are consumers in a culture of individualism and low uncertainty avoidance. The rationale behind this proposition is that in a high uncertainty avoidance culture, where solidarity or tightness is valued, and in a collectivism culture, where strong interpersonal ties and a "we" consciousness prevail, consumers tend to judge others to be similar to themselves. That is, in collectivism and high uncertainty avoidance cultures, trust is more likely to be transferred because individuals tend to judge the target(trust) to be similar to the source (firm reputation). In other words, brand equity is a solid proof source from which trust is determined. As Korea represents collectivism and a high uncertainty avoidance culture, brand equity can be relatively easily transferred to trust (Jin, Yong Park and Kim, 2008)

$\mathrm{H} 2$ : The effect of brand equity on trust is higher in Korea than in United States.

\subsection{Relationship Equity and Trust}

Relationship equity involves special relationship elements that link customers to the company and its brand and strengthens these relationships beyond value and brand equity (Richards and Jones, 2008). If the perceived relationship equity is high, customers believe that they are well treated and handled with particular care (Vogel, Evanschitzky and Ramaseshan, 2008). Once customers who visiting large retail stores satisfied with its quality and service, there are more likely to visit the store again, which generate the trust toward the large retail store. The tendency to form long term relationships eventually leads to a state of inertia between buyer and seller which is unwillingness of both parties to bring the 
relationship to an end unless something went exceptionally wrong (Gounaris and Venetis, 2002). Many studies report that cultures with high uncertainty avoidance (Korea) resist change and thus are not likely to end valued relationships (Kale and Barnes, 1992). Consumers in a collectivism and high risk aversion (Korea), the relationship between consumers and a retailing brand is more sticker (higher trust) than of individualistic and low risk aversion (USA). Generally, when facing risk-taking decision such as brand switching or taking new experience, their perceived risk with collectivism is higher than that of individualistic cultures (Erdem, Zhao and Valenzuela, 2004). Hence we propose the following hypotheses regarding the effect of relationship equity of trust:

H3: The effect of relationship equity on trust is higher in Korea than in United States.

\subsection{Trust and Satisfaction and Trust and Loyalty}

One of the characteristics of Hofstede's individualism is trusting of others; individualism promotes a trusting stance; one gets better outcomes assuming that others are reliable. Hence, individualists are much more likely to trust others until they are given some reason not to trust. By contrast, members of collectivism are more likely to base their trust on relationships with first-hand knowledge. That is, they confined themselves to existing in group relationships and withhold trusting others. Due to their emphasis on social relatedness and interdependence, collectivist cultures are sensitive to the in-group-outgroup boundary. (Yamagishi and Yamagishi, 1994). A similar idea is found in Fukuyama's (1995) work. According to Fukuyama (1995), in a low-trust society, such as Korea, members are less likely to trust someone who is not part of their in-group, which deters the creation of corporate organizations that are critical in successful modern economics. Trust also contributes to economic efficiency. A high-trust society allows flexibility and is therefore able to function with fewer regulations and lower transaction costs (Galston, 1996). When trust is exercised a great deal in a society (i.e. USA), it can be hypothesized that the impact of trust on subsequent consumer behaviour (i.e. satisfaction and loyalty) is more direct (without intervening factors) and stronger than in a low-trust society. Therefore, we put the following prediction:

H4: The effect of trust on satisfaction is higher in the United States than in Korea.

H5: The effect of trust on loyalty is higher in the United States than in Korea.

\subsection{Satisfaction and Loyalty}

It is commonly known that a strong link exists between satisfaction and customer loyalty. Szymanski and Henard's (2001) meta-analysis shows that satisfaction has a positive impact on loyalty. While empirical findings with regard to cultural differences in the satisfaction-loyalty link have not been provided, several studies 
propose satisfaction-loyalty link in cultural differences. Liu, Furrer and Sudharshan (2001) found in the bank industry of collectivistic or high uncertainty avoidance cultures (i.e. Korea), consumers tend not to switch or complain even when they receive poor service if they were once satisfied with the service, while in higher individualism or lower uncertainty avoidance cultures (i.e. USA), consumers tend to switch or complain when they receive poor service even if they had high satisfaction during their previous experience. Thus, we put the following hypothesis:

H6: The effect of satisfaction on loyalty is higher in United States than in Korea.

\section{RESEARCH METHOD}

\subsection{Survey Design and Data Collection}

We collected data from two countries: Korea and USA, because they are representative of Western and Eastern culture. The original questionnaire was initially developed in English as shown Tab. 1. Then, English questionnaire was translated into Korean by an individual fluent in both English and Korean. The questionnaire was then back-translated into English. We pre-tested both questionnaires to check for the comprehensibility of the instructions, construct, wording and layout in both countries. Respondents were asked to recall a recent visit to their most preferred discount stores. Each item was rated on a five-point Likert scale ranging from "strongly disagree" (1) to "strongly agree" (5). Information on demographic characteristics and discount store shopping behaviour was also obtained. Respondents were asked about their age, gender and what they shopped at that store.

Table 1 - Measurement Items

\begin{tabular}{|c|c|c|c|}
\hline Variables & Item & Content & Reference \\
\hline Value equity & $\begin{array}{l}\text { Val1 } \\
\text { Val2 } \\
\text { Val3 } \\
\text { Val4 } \\
\text { Val5 }\end{array}$ & $\begin{array}{l}\text { Worthwhile } \\
\text { High quality and service } \\
\text { Proper pricing that matches its quality } \\
\text { Easy exchange and refund policy } \\
\text { Items are displayed appropriate for shopping }\end{array}$ & $\begin{array}{l}\text { Vogel et al. (2008) } \\
\text { Roland et al. (2000) }\end{array}$ \\
\hline Brand equity & $\begin{array}{l}\mathrm{Br} 1 \\
\mathrm{Br} 2 \\
\mathrm{Br} 3 \\
\mathrm{Br} 4 \\
\mathrm{Br} 5 \\
\mathrm{Br} 6\end{array}$ & $\begin{array}{l}\text { Have good reputation } \\
\text { Innovation } \\
\text { Have High ethical standards } \\
\text { Remember store's logos or symbols } \\
\text { Come up with good images } \\
\text { Different from others }\end{array}$ & $\begin{array}{l}\text { Aaker and Equity } \\
\text { (1991) }\end{array}$ \\
\hline $\begin{array}{l}\text { Relationship } \\
\text { equity }\end{array}$ & Rel1 & $\begin{array}{l}\text { Do services that they don't do for most } \\
\text { customers }\end{array}$ & $\begin{array}{l}\text { Hennig-Thurau, } \\
\text { Gwinner and Gremler } \\
(2002)\end{array}$ \\
\hline
\end{tabular}




\begin{tabular}{|c|c|c|c|}
\hline Variables & Item & Content & Reference \\
\hline & $\begin{array}{l}\text { Rel2 } \\
\text { Rel3 } \\
\text { Rel4 } \\
\text { Rel5 }\end{array}$ & $\begin{array}{l}\text { Send information that is relevant to my } \\
\text { purchase } \\
\text { Seen a large retail store in social network sites } \\
\text { Participate in the social network communities } \\
\text { Feel intimacy toward a large retail store }\end{array}$ & \\
\hline Trust & $\begin{array}{l}\text { Tru1 } \\
\text { Tru2 } \\
\text { Tru3 } \\
\text { Tru4 }\end{array}$ & $\begin{array}{l}\text { Believe a large retail store will not try to cheat } \\
\text { Trust a large retail store completely } \\
\text { Feel secure when use products } \\
\text { Would make every effort to satisfy me }\end{array}$ & Lau and Lee (1999) \\
\hline Satisfaction & $\begin{array}{l}\mathrm{Sa} 1 \\
\mathrm{Sa} 2 \\
\mathrm{Sa} 3\end{array}$ & $\begin{array}{l}\text { Experience in large retail store has been } \\
\text { satisfactory } \\
\text { I am satisfied with the way that the store } \\
\text { functions } \\
\text { Made correct decision to use }\end{array}$ & $\begin{array}{l}\text { Flavián, Guinalíu and } \\
\text { Gurrea (2006) }\end{array}$ \\
\hline Loyalty & $\begin{array}{l}\text { Loy1 } \\
\text { Loy2 } \\
\text { Loy3 } \\
\text { Loy4 }\end{array}$ & $\begin{array}{l}\text { I am committed to a large retail store } \\
\text { I say positive things about a large retail store } \\
\text { to other } \\
\text { I recommend the company to anyone who } \\
\text { seeks my advice } \\
\text { I am going to revisit in the future }\end{array}$ & $\begin{array}{l}\text { Zeithaml, Berry and } \\
\text { Parasuraman (1996) } \\
\text { Quester and Lin Lim } \\
(2003)\end{array}$ \\
\hline
\end{tabular}

A total of 430 responses were collected (Korea: 210; USA: 220). After removing incomplete responses, a total of 198 Korean and 199 American were used to test the proposed model. Participant's demographics are shown in Tab. 2.

Table 2 - Demographic Characteristics of Samples

\begin{tabular}{|l|l|c|c|}
\hline \multicolumn{2}{|c|}{ Classification } & USA(n=199) & Korea(n=198) \\
\hline Gender & Male & 127 & 121 \\
& Female & 72 & 77 \\
\hline Age & $10 \sim 19$ & 2 & 2 \\
& $20 \sim 29$ & 85 & 127 \\
& $30 \sim 39$ & 66 & 50 \\
& $40 \sim 49$ & 24 & 4 \\
& $50 \sim 59$ and above & 22 & 15 \\
\hline Population & Big city & 33 & 144 \\
& Middle to small city & 87 & 35 \\
& Rural area & 79 & 19 \\
\hline What to buy & Electronic Appliances & 45 & 1 \\
& Clothing & 14 & 113 \\
& Daily Necessity & 77 & 74 \\
\hline Transportation & Fresh Food & 67 & 46 \\
& Etc & 170 & 5 \\
& By automobile, car & 18 & 97 \\
\hline
\end{tabular}




\section{RESUTS}

\subsection{Measurement Item Testing}

Data analysis was conducted using the partial least squares (PLS) technique. PLS was chosen because PLS is not as restrictive on the sample as covariance-based structural equation modelling (SEM) methods that require a separate multisample analysis for interaction effects along with relatively large sample sizes and multivariate normal data distributions (Jöreskog and Sörbom, 1989).

Table 3 - AVE, CR, and Discriminant Validity of Constructs

\begin{tabular}{|c|c|c|c|c|c|c|c|c|c|}
\hline & AVE & CR & $\begin{array}{c}\text { Cronbach } \\
\text { alpha }\end{array}$ & VAL & BR & REL & TRU & SA & LOY \\
\hline \multirow[t]{2}{*}{ VAL } & $0.69(\mathrm{k})$ & $0.82(\mathrm{k})$ & $0.61(\mathrm{k})$ & $\mathbf{0 . 8 3}(\mathrm{k})$ & & & & & \\
\hline & $0.55(\mathrm{u})$ & $0.78(\mathrm{u})$ & $0.62(\mathrm{u})$ & $0.74(\mathrm{u})$ & & & & & \\
\hline \multirow[t]{2}{*}{ BR } & $0.54(\mathrm{k})$ & $0.82(\mathrm{k})$ & $0.72(\mathrm{k})$ & $0.45(\mathrm{k})$ & $\mathbf{0 . 7 3}(\mathrm{k})$ & & & & \\
\hline & $0.70(\mathrm{u})$ & $0.87(\mathrm{u})$ & $0.78(\mathrm{u})$ & $0.60(\mathrm{u})$ & $0.84(\mathrm{u})$ & & & & \\
\hline \multirow[t]{2}{*}{ REL } & $0.63(\mathrm{k})$ & $0.83(\mathrm{k})$ & $0.70(\mathrm{k})$ & $0.39(\mathrm{k})$ & $0.59(\mathrm{k})$ & $\mathbf{0 . 7 9}(\mathrm{k})$ & & & \\
\hline & $0.72(\mathrm{u})$ & $0.83(\mathrm{u})$ & $0.62(\mathrm{u})$ & $0.38(\mathrm{u})$ & $0.52(\mathrm{u})$ & $\mathbf{0 . 8 5}(\mathrm{u})$ & & & \\
\hline \multirow[t]{2}{*}{ TRU } & $0.66(\mathrm{k})$ & $0.88(\mathrm{k})$ & $0.82(\mathrm{k})$ & $0.45(\mathrm{k})$ & $0.58(\mathrm{k})$ & $0.57(\mathrm{k})$ & $0.81(k)$ & & \\
\hline & $0.74(\mathrm{u})$ & $0.92(\mathrm{u})$ & $0.89(\mathrm{u})$ & $0.54(\mathrm{u})$ & $0.65(\mathrm{u})$ & $0.54(\mathrm{u})$ & $\mathbf{0 . 8 6}(\mathrm{u})$ & & \\
\hline \multirow[t]{2}{*}{ SA } & $0.66(\mathrm{k})$ & $0.86(\mathrm{k})$ & $0.75(\mathrm{k})$ & $0.47(\mathrm{k})$ & $0.40(\mathrm{k})$ & $0.45(\mathrm{k})$ & $0.62(\mathrm{k})$ & $\mathbf{0 . 8 1}(\mathrm{k})$ & \\
\hline & $0.80(\mathrm{u})$ & $0.92(\mathrm{u})$ & $0.87(\mathrm{u})$ & $0.58(\mathrm{u})$ & $0.61(\mathrm{u})$ & $0.42(\mathrm{u})$ & $0.54(\mathrm{u})$ & $\mathbf{0 . 8 9}(\mathrm{u})$ & \\
\hline \multirow[t]{3}{*}{ LOY } & $0.67(\mathrm{k})$ & $0.89(\mathrm{k})$ & $0.83(\mathrm{k})$ & $0.42(\mathrm{k})$ & $0.42(\mathrm{k})$ & $0.34(\mathrm{k})$ & $0.57(\mathrm{k})$ & $0.63(\mathrm{k})$ & $\mathbf{0 . 8 3}(\mathrm{k})$ \\
\hline & $0.82(\mathrm{u})$ & $0.93(\mathrm{u})$ & $0.89(\mathrm{u})$ & $0.21(\mathrm{u})$ & $0.36(\mathrm{u})$ & $0.19(\mathrm{u})$ & $0.33(\mathrm{u})$ & $0.27(\mathrm{u})$ & $0.91(u)$ \\
\hline & $\begin{array}{l}\text { Leadins } \\
\text { K: Kore }\end{array}$ & iagon & hows th & $\operatorname{ared~} r$ & tof $A$ & of eac & onstru & & \\
\hline
\end{tabular}

Before doing multi group comparisons, it is always important to first establish the measures perform adequately in both data samples. To conceptually validate the instrument, we assessed the constructs for convergent and discriminant validity. Convergent validity can be established by examining standardized path loadings of items, composite reliability (CR), Cronbach's alpha, and the average variance extracted (AVE) of constructs (Gefen, Straub and Boudreau, 2000). The standardized path loadings of all items were significant (t-value $>1.96$ ) and 
greater than 0.7. Internal reliability for each construct was assessed using Cronbach's alpha. Reliability for all constructs exceeded the suggested level of 0.60 (Nunnally, 1978). This indicates that each of the constructs was adequately captured by its indicators. The CR and AVE for all constructs exceeded 0.7 and 0.5 . Thus, each test result met its threshold criterion, and the convergent validity for the constructs was supported.

Discriminant validity of a measurement model is supported when the square root of AVE for each construct is greater than the correlations between that construct and other constructs (Fornell and Larcker, 1981). As shown in Tab. 3, this condition was satisfied.

\subsection{Structural Model Testing}

We conducted Chin's (2000) multi-group PLS analysis to compare between two group differences (South Korea and USA) which is shown in Fig. 2. It is performed by taking the standard errors for the structural model paths and comparing the equivalent paths across different groups (South Korea and USA in this study) by performing t-tests on their path coefficients.

$$
t=\frac{\text { Path }_{\text {sample_1 }_{-}-\text {Path }_{\text {sample } 2} 2}}{\left.\sqrt{\frac{m-1}{(m+n-2)} * S . E_{\text {sample }_{-} 2}^{2}}\right] *\left[\sqrt{\frac{1}{m}+\frac{1}{n}}\right]}
$$

Where:

$S . E$ is the standard error.

Path $_{\text {sample }}$ is the path coefficients in each structural model.

$m, n$ are the sample sizes of dataset.

$(m+n-2)$ is the degree of freedom.

The significance of the paths was determined using the t-statistical test calculated with the bootstrapping technique (with subsampling of 500). The results of PLS analyses for the Korean and the American models are shown in Fig. 2, Fig. 3, and Tab. 4 respectively. 


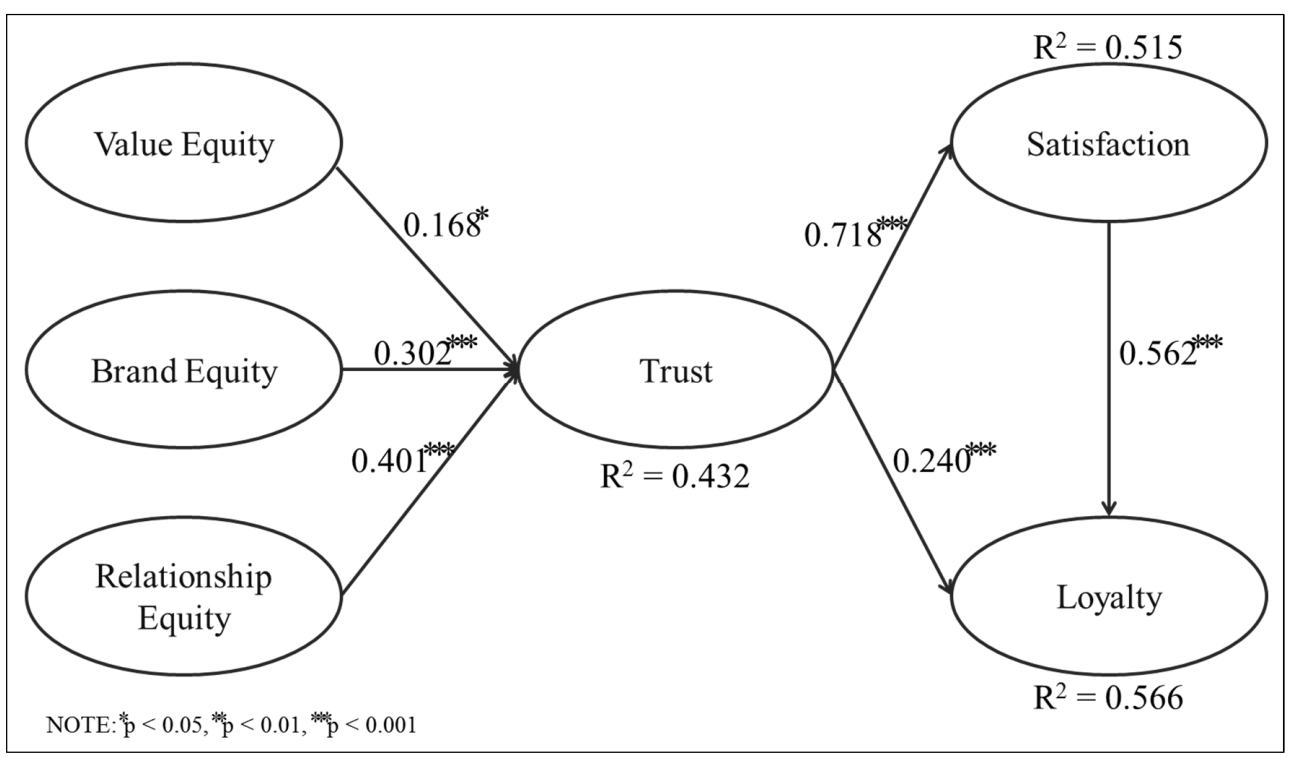

Figure 2 - Results of the Structural Model (KOR)



Figure 3 - Results of the Structural Model (USA) 
Table 4 - Statistical Comparison of Paths

\begin{tabular}{|llllll|}
\hline & \multicolumn{4}{l}{ Korea(n=198) } & \multicolumn{3}{l|}{ United States(n=199) } \\
\hline Path & $\begin{array}{l}\text { Path } \\
\text { coefficient }\end{array}$ & $\begin{array}{l}\text { Standard } \\
\text { error }\end{array}$ & $\begin{array}{l}\text { Path } \\
\text { coefficient }\end{array}$ & $\begin{array}{l}\text { Standard } \\
\text { error }\end{array}$ & $\begin{array}{l}\text { Statistical } \\
\text { comparison of paths }\end{array}$ \\
\hline Value equity $\rightarrow$ Trust & 0.168 & 0.065 & 0.191 & 0.065 & $3.525^{* * *}$ \\
Brand equity $\rightarrow$ Trust & 0.302 & 0.076 & 0.401 & 0.069 & $13.590^{* * *}$ \\
Relationship equity $\rightarrow$ Trust & 0.401 & 0.074 & 0.262 & 0.056 & $21.110^{* * *}$ \\
Trust $\rightarrow$ Satisfaction & 0.718 & 0.038 & 0.642 & 0.042 & $18.903^{* * *}$ \\
Trust $\rightarrow$ Loyalty & 0.270 & 0.077 & 0.247 & 0.093 & $3.150^{* *}$ \\
Satisfaction $\rightarrow$ Loyalty & 0.562 & 0.075 & 0.000 & 0.117 & $56.944^{* * *}$ \\
\hline
\end{tabular}

Tab. 4 depicts the statistical comparison of paths between the two cultural data sets. The results confirm that there are significant differences in the effect of customer equity drivers on customer loyalty via trust and satisfaction between Korea and USA.

\section{CONCLUSION}

\subsection{Discussion of Findings}

We investigated the impact of the three drivers of customer equity on loyalty via trust and satisfaction in two different countries, Korea and USA. The results show that there are significant differences in the effects of customer drivers on customer loyalty via trust and satisfaction in large retail industries. To highlight some of the differences, value equity and brand equity had stronger influence on trust in USA. And relationship equity had a larger effect on trust in Korea. And while Satisfaction had some effects on building their loyalty in Korea, satisfaction had no effect in gaining customers' loyalty in USA. For value equity, this findings consistent with Bao, Zhou and Su (2003) who claim that unlike Asian consumers who are more sensitive in extrinsic variables like brand, country of origin and firm reputation, western consumers have a higher valuefor-money orientation and more sensitive in intrinsic attributes such as price and quality. Contrary to our hypotheses, Brand equity has more positive influence on building consumer's trust in USA than in Korea. This result contradicts with previous research findings by Liao and Wang (2009) that Asian consumers would be more brands orientated than Western consumers because of their desire to express social self-worth. It leads to the conclusion that, in Korea, branding seems to be less important for building consumer's trust in retail industries. Furthermore, Relationship equity is found to be more influenced on consumer's trust in Korea than in USA as we expected. This finding is consistent with previous literature that generally Korean consumers care more about the quality 
of their interactions with employees such that they may become one of in-group members and get preferential treatments like free gifts or services. However, there is a notable difference in the link between satisfaction and loyalty in two countries. The cross cultural analysis of relationships between satisfaction and loyalty are well established in previous studies and results are generally positive. And our study also shows a positive relationship between satisfaction and loyalty in Korea, but no impact in USA. Normally, once customers are satisfied with products or services, they will have a positive impact on customer loyalty. However, Jones (1996) claims that the link between satisfaction and loyalty is not absolutely positive results. Some prior researchers have found that variety of factors such as product usage, switching costs, consumer knowledge, and sociodemographic (e.g., age, income, and gender) moderate the relationship between satisfaction and loyalty (Homburg and Giering, 2001; Mittal and Kamakura, 2001). The absence of link between satisfaction and loyalty in USA could be explained by cultural differences on our demographic characteristics of samples shown in Tab. 2. It shows the demographic characteristics of the two data sets which are different in terms of age. In Korea, our sample includes mostly from age of 20's and 30's. It may not represent the general population and believe this sociodemographic factor might moderate the relationship between satisfaction and loyalty.

\subsection{Implications and Limitations}

The customer equity drivers that link with loyalty research has been studied and discussed widely by some scholars. Also, there is a similar research conducting the effect of customer drivers on loyalty via consumer trust in B2B context. But the cross cultural studying of these is still limited. In order to success entry in to the market of other countries, a good strategy of understanding and melt into the host country's culture is very important, particularly for international marketing. Accordingly, we empirically validated and extended existing customer equity model to large retail stores in cross cultural studying by examine of how each customer equity drivers effect on customer loyalty via trust and satisfaction.

Our study offers some important implications for managers. In collectivism cultures such as Korea, Relationship equity shows the most significant impacts on loyalty via trust and satisfaction. So it is more efficient for MNC managers to consider on customer focused marketing to develop on quality relationships with customers. These marketing efforts such as loyalty programs, communitybuilding programs, and special recognition and treatment could enhance consumers' trust and thus increasing consumers' loyalty. In contrast, in more individualistic cultures like USA, value and brand equity are of primary importance in establishing customer loyalty via trust and satisfaction. The importance of value equity depends on the industry, the maturity of the firm, and the customer-decision process, it is important that managers uncover level of influence of various aspects of value on loyalty for different customer segments in their business to that resources can be appropriately allocated, thus 
maximizing value equity. MNC managers should choose from several possibilities to strengthen the value perception in the customer's mind, such as offering low prices, improving the quality of assortment, and enhancing store ambience to maximize value equity. Also, MNC managers should focus on brand marketing to build strong and favourable brand image. As there are many competing suppliers in the retail industry, branding is especially important to influence customer perceptions positively and drive store choice generating trust and loyalty. Understanding the changing consumer environment and constantly upgrading the brand to ensure that the brand maintains its level that meets the customer's needs will help managers to enhance brand equity (Vogel, Evanschitzky and Ramaseshan, 2008).

A couple of limitations of this study suggest potential research opportunities. As our Korean sample are limited to ages of 20's to 30's, mostly students and nonmarriage workers, these populations may not represent the perceptions of the general population. For future research, a sample should be including more diverse groups of ages to be more representative of the target market of discount stores. As trust is developed thorough various routes and through a dynamic process, diverse aspects of trust need to be accounted for in future research. In addition, ongoing research should verify and extend our model with different countries to determine whether the cultural differences are stable. Also, as customer equity drivers may affect differently according to the market, new areas of markets need to be explored for the future. We used PLS for data analysis and multi-group PLS analysis method (Chin, 2000) is conducted to compare between two group differences. Besides using a PLS technique, AMOS multi group analysis is also known as group comparison tools and it can be used as data analysis and this could be yield different results. Also, it would be interesting to compare the level of significance for the differences in structural paths as provided by AMOS with those from PLS.

\section{ACKNOWLEGEMENT}

This work was supported by the Sun Moon University Research Grant of 2017.

\section{REFERENCES}

Aaker, D.A. and Equity, M.B., 1991. Capitalizing on the Value of a Brand Name. New York, NY: Free Press.

Anderson, E.W., Fornell, C. and Lehmann, D.R., 1994. Customer satisfaction, market share, and profitability: Findings from Sweden. The Journal of marketing, 58(3), pp.53-66.

Atuahene-Gima, K. and Li, H., 2002. When does trust matter? Antecedents and contingent effects of supervisee trust on performance in selling new products in China and the United States. Journal of Marketing, 66(3), pp.61-81. 
Bao, Y., Zhou, K.Z. and Su, C., 2003. Face consciousness and risk aversion: do they affect consumer decision-making?. Psychology and Marketing, 20(8), pp.733-755.

Bond, R. and Smith, P.B., 1996. Culture and conformity: A meta-analysis of studies using Asch's (1952b, 1956) line judgment task. Psychological bulletin, 119(1), pp.111-137.

Brady, M.K., Robertson, C.J. and Cronin, J.J., 2001. Managing behavioral intentions in diverse cultural environments: An investigation of service quality, service value, and satisfaction for American and Ecuadorian fast-food customers. Journal of International Management, 7(2), pp.129-149.

Chin, W.W., 2000. Frequently asked questions-partial least squares and PLSgraph. Available at: <http://disc-nt.cba.uh.edu/chin/plsfaq.htm\#Q1>.

Chung, N. and Kwon, S.J., 2009. Effect of trust level on mobile banking satisfaction: a multi-group analysis of information system success instruments. Behaviour and Information Technology, 28(6), pp.549-562.

De Mooij, M. and Hofstede, G., 2011. Cross-cultural consumer behavior: A review of research findings. Journal of International Consumer Marketing, 23(34), pp.181-192.

Delgado-Ballester, E. and Luis Munuera-Alemán, J., 2001. Brand trust in the context of consumer loyalty. European Journal of Marketing, 35(11/12), pp.1238-1258.

Dwivedi, A., Merrilees, B., Miller, D. and Herington, C., 2012. Brand, value and relationship equities and loyalty-intentions in the Australian supermarket industry. Journal of Retailing and Consumer Services, 19(5), pp.526-536.

Eggert, A. and Ulaga, W., 2002. Customer perceived value: a substitute for satisfaction in business markets?. Journal of Business and Industrial Marketing, 17(2/3), pp.107-118.

Erdem, T., Zhao, Y. and Valenzuela, A., 2004. Performance of store brands: A cross-country analysis of consumer store-brand preferences, perceptions, and risk. Journal of Marketing Research, 41(1), pp.86-100.

Flavián, C., Guinalíu, M. and Gurrea, R., 2006. The role played by perceived usability, satisfaction and consumer trust on website loyalty. Information and Management, 43(1), pp.1-14.

Fornell, C. and Larcker, D.F., 1981. Evaluating structural equation models with unobservable variables and measurement error. Journal of Marketing Research, 18(1), pp.39-50.

Fukuyama, F., 1995. Trust: The social virtues and the creation of prosperity. New York, NY: Free Press. 
Galston, W.A., 1996. Trust--But quantify--Trust: The Social Virtues and the Creation of Prosperity by Francis Fukuyama. Public Interest, 122, pp.129-132.

Gefen, D., Straub, D. and Boudreau, M.C., 2000. Structural equation modeling and regression: Guidelines for research practice. Communications of the association for information systems, 4(1), pp.2-77.

Gounaris, S.P. and Venetis, K., 2002. Trust in industrial service relationships: behavioral consequences, antecedents and the moderating effect of the duration of the relationship. Journal of Services Marketing, 16(7), pp.636-655.

Henderson, P.W., Cote, J.A., Leong, S.M. and Schmitt, B., 2003. Building strong brands in Asia: selecting the visual components of image to maximize brand strength. International Journal of Research in Marketing, 20(4), pp.297-313.

Hennig-Thurau, T., Gwinner, K.P. and Gremler, D.D., 2002. Understanding relationship marketing outcomes an integration of relational benefits and relationship quality. Journal of Service Research, 4(3), pp.230-247.

Hofstede, G.H. and Hofstede, G., 2001. Culture's consequences: Comparing values, behaviors, institutions and organizations across nations. Thousand Oaks, CA: Sage Publications.

Homburg, C. and Giering, A., 2001. Personal characteristics as moderators of the relationship between customer satisfaction and loyalty - an empirical analysis. Psychology and Marketing, 18(1), pp.43-66.

Jöreskog, K.G. and Sörbom, D., 1989. LISREL 7: A guide to the program and applications. IL,Chicago: SPSS.

Jin, B., Yong Park, J. and Kim, J., 2008. Cross-cultural examination of the relationships among firm reputation, e-satisfaction, e-trust, and e-loyalty. International Marketing Review, 25(3), pp.324-337.

Jones, T.O., 1996. Why satisfied customers defect. Journal of Management in Engineering, 12(6), pp.11.

Kale, S.H. and Barnes, J.W., 1992. Understanding the domain of cross-national buyer-seller interactions. Journal of International Business studies, 23(1), pp.101-132.

Lau, G.T. and Lee, S.H., 1999. Consumers' trust in a brand and the link to brand loyalty. Journal of Market-Focused Management, 4(4), pp.341-370.

Lee, M. and Ulgado, F.M., 1997. Consumer evaluations of fast-food services: a cross-national comparison. Journal of Services Marketing, 11(1), pp.39-52.

Lemon, K.N., Rust, R.T. and Zeithaml, V.A., 2001. What drives customer equity?. Marketing Management, 10(1), pp.20-25.

Liao, J. and Wang, L., 2009. Face as a mediator of the relationship between material value and brand consciousness. Psychology and Marketing, 26(11), pp.987-1101. 
Liu, B.S., Furrer, O. and Sudharshan, D., 2001. The relationships between culture and behavioral intentions toward services. Journal of Service Research, 4(2), pp.118-129.

Liu, R.R. and McClure, P., 2001. Recognizing cross-cultural differences in consumer complaint behavior and intentions: an empirical examination. Journal of Consumer Marketing, 18(1), pp.54-75.

Lowe, C-T.A. and Corkindale, D.R., 1998. Differences in "cultural values" and theireffects on responses to marketing stimuli: A cross-cultural study between Australians and Chinese from the People's Republic of China. European Journal of Marketing, 32(9/10), pp.843-867.

Mittal, V. and Kamakura, W.A., 2001. Satisfaction, repurchase intent, and repurchase behavior: Investigating the moderating effect of customer characteristics. Journal of Marketing Research, 38(1), pp.131-142.

Nunnally, J.C., 1978. Psychometric theory. New York, NY: McGraw-Hill.

Park, C.-H. and Kim, Y.-G., 2003. Identifying key factors affecting consumer purchase behavior in an online shopping context. International Journal of Retail and Distribution Management, 31(1), pp.16-29.

Quester, P. and Lin Lim, A., 2003. Product involvement/brand loyalty: is there a link?. Journal of product and brand management, 12(1), pp.22-38.

Ramaseshan, B., Rabbanee, F.K. and Tan Hsin Hui, L., 2013. Effects of customer equity drivers on customer loyalty in B2B context. Journal of Business and Industrial Marketing, 28(4), pp.335-346.

Reichheld, F.F. and Schefter, P., 2000. E-loyalty: your secret weapon on the web. Harvard business review, 78(4), pp.105.

Richards, K.A. and Jones, E., 2008. Customer relationship management: Finding value drivers. Industrial Marketing Management, 37(2), pp.120-130.

Rust, R.T., Lemon, K.N. and Zeithaml, V.A., 2004. Return on marketing: Using customer equity to focus marketing strategy. Journal of Marketing, 68(1), pp.109-127.

Shapiro, B.P., 1973. Price reliance: existence and sources. Journal of Marketing Research, 10(3), pp.286-294.

Singh, J. and Sirdeshmukh, D., 2000. Agency and trust mechanisms in consumer satisfaction and loyalty judgments. Journal of the Academy of Marketing Science, 28(1), pp.150-167.

Sirohi, N., McLaughlin, E.W. and Wittink, D.R., 1998. A model of consumer perceptions and store loyalty intentions for a supermarket retailer. Journal of Retailing, 74(2), pp.223-245. 
Szymanski, D.M. and Henard, D.H., 2001. Customer Satisfaction: A MetaAnalysis of the Empirical Evidence. Journal of the Academy of Marketing Science, 29(1). pp.16-35.

Ting-Toomey, S. and Kurogi, A., 1998. Facework competence in intercultural conflict: An updated face-negotiation theory. International Journal of Intercultural Relations, 22(2), pp.187-225.

Verhoef, P.C., Langerak, F. and Donkers, B., 2007. Understanding brand and dealer retention in the new car market: The moderating role of brand tier. Journal of Retailing, 83(1), pp.97-113.

Vogel, V., Evanschitzky, H. and Ramaseshan, B., 2008. Customer Equity Drivers and Future Sales. Journal of Marketing, 72(6), pp.98-108.

Yamagishi, T. and Yamagishi, M., 1994. Trust and commitment in the United States and Japan. Motivation and Emotion, 18(2), pp.129-166.

Yang, Z. and Peterson, R.T., 2004. Customer perceived value, satisfaction, and loyalty: The role of switching costs. Psychology and Marketing, 21(10), pp.799822.

Zeithaml, V.A., 1988. Consumer perceptions of price, quality, and value: a means-end model and synthesis of evidence. The Journal of marketing, 52(3), pp.2-22.

Zeithaml, V.A., Berry, L.L. and Parasuraman, A., 1996. The behavioral consequences of service quality. The Journal of marketing, 52(3), pp.31-46.

Zhang, S.S., Van Doorn, J. and Leeflang, P.S., 2014. Does the importance of value, brand and relationship equity for customer loyalty differ between Eastern and Western cultures?. International Business Review, 23(1), pp.284-292.

\section{ABOUT AUTHORS}

Insu Cho is Assistant professor of Department of Industrial and Management Engineering in Sun Moon University, South Korea. He is in charge of Quality Management, e-mail: incho@sunmoon.ac.kr.

Yong Soo Jang is Master of Department of Information and Industrial Engineering in Yonsei University, South Korea, e-mail: Andie86@yonsei.ac.kr.

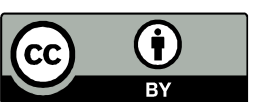

(C) 2017 by the authors. Submitted for possible open access publication under the terms and conditions of the Creative Commons Attribution (CC-BY) license (http://creativecommons.org/licenses/by/4.0/). 